\title{
Sporadic haemangioblastoma of the kidney with rhabdoid features and focal CD10 expression: report of a case and literature review
}

Wei-hua Yin ${ }^{1}$, Jian $\mathrm{Li}^{1 *}$ and John KC Chan ${ }^{2}$

\begin{abstract}
We present here an intriguing case of sporadic renal haemangioblastoma occurring in a 61-year-old male. The tumor consisted of nests of polygonal cells and abundant capillary networks. The neoplastic cells generally showed abundant eosinophilic cytoplasm and prominent eccentric nuclei, resembling the rhabdoid cells. Pronounced intranuclear cytoplasmic pseudoinclusions were another significant feature seen. NSE, a-inhibin and S100 were positive in tumor cells and particularly, focal CD10 expressions were observed. This is possibly the first reported case of a haemangioblastoma showing a rhabdoid phenotype and CD10 immunopositivity. Malignant rhabdoid tumor and renal cell carcinoma with rhabdoid features were probably the most challenging mimics need to be differentiated. The result of focal CD10 staining in our case may further lead to confusion with renal cell carcinoma. To avoid misdiagnosis, more considerations should be attached to the rare neoplasm.
\end{abstract}

Virtual Slides: The virtual slide(s) for this article can be found here: http://www.diagnosticpathology.diagnomx.eu/ vs/1068858553657049

Keywords: Haemangioblastoma, Kidney, CD10, Rhabdoid features

\section{Background}

Haemangioblastoma is a slowly growing, highly vascular benign tumor, corresponding to WHO grade I. It typically arises within the central nervous system (CNS), but may occasionally originate in unusual sites such as peripheral nerve, bone, soft tissue, skin, liver, lung and pancreas [1-3], and maybe associated with von Hippel-Lindau (VHL) disease.

The kidney is another rare site for the development of sporadic haemangioblastoma growth, and only four cases have been reported in the English-language literature so far [4-6]. The accurate diagnosis is often challenging when the tumor develops in this region. We described herein the fifth case of this rare tumor, which notably demonstrated a rhabdoid phenotype as well as unexpected CD10 staining. In addition, the shared characteristics of renal haemangioblastomas (RHB) and their differential considerations were also discussed in detail.

\footnotetext{
* Correspondence: lijianhouma@yahoo.cn

'Department of Pathology, Peking University Shenzhen Hospital, No.1120

Lianhua North Road, Shenzhen 518000, China

Full list of author information is available at the end of the article
}

\section{Case presentation}

A 61-year-old man was admitted to our hospital for a solid mass found in the right kidney during a routine checkup. Computed tomography showed that the mass was located in the superior pole. No remarkable symptoms such as flank pain or urinary irritation were reported by the patient. He also had no familial history or clinical evidences of VHL disease. Radical nephrectomy was carried out, showing a $5.3 \times 5.0 \times 5.0 \mathrm{~cm}$ mass. It was grey to yellowish in color and well-demarcated from the surrounding renal parenchyma. The patient had an uneventful postoperative recovery and was well at 12 months follow-up.

\section{Histopathological and Immunohistochemical findings}

Microscopically, the specimen consisted of nests of polygonal tumor cells and a prominent capillary network. Focal areas of necrosis were present. The stroma showed extensive fibrosis and hyalinization, which amounted to approximately one third of the lesion (Figure 1A, B).

\section{C) Biomed Central}

(C) 2012 Yin et al; licensee BioMed Central Ltd. This is an Open Access article distributed under the terms of the Creative Commons Attribution License (http://creativecommons.org/licenses/by/2.0), which permits unrestricted use, distribution, and reproduction in any medium, provided the original work is properly cited. 


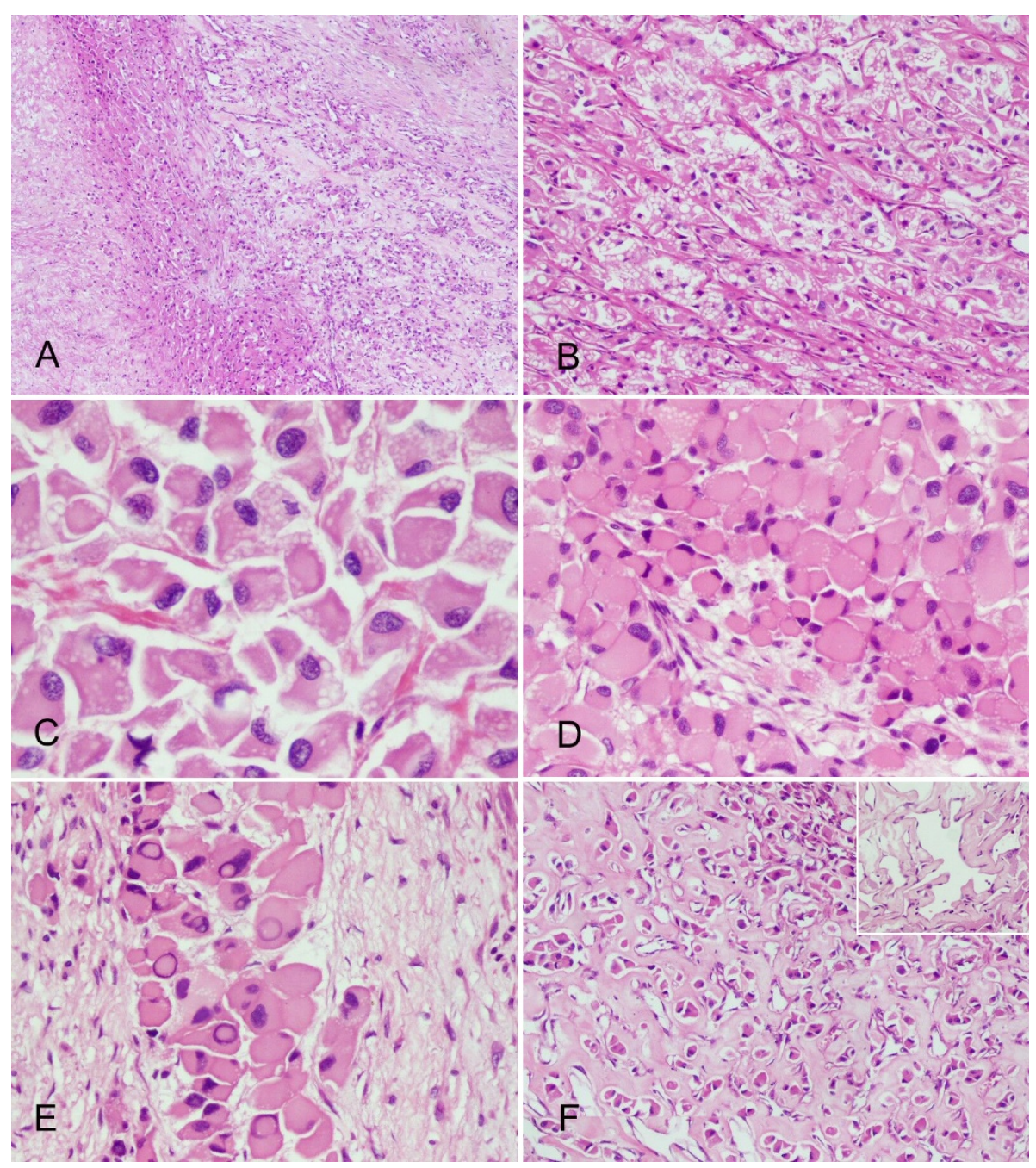

Figure 1 Histopathological findings of the renal hemangioblastoma. (A) Stromal hyalinization was prominent among the neoplasm and foci of necrosis were observed inside the tumor (left field) (H\&E staining, with original magnification $\times 40$ ). (B) The tumor cells were arranged in nests and traversed by a vascular network (H\&E staining, with original magnification $\times 100)$. (C) Lipid vesicles were abundant in some tumor cells $(H \& E$ staining, with original magnification $\times 400$ ). (D) The tumor cells had enlarged eosinophilic cytoplasm and eccentrically-displaced nuclei, exhibiting a rhabdoid phenotype (H\&E staining, with original magnification $\times 200$ ). (E) Pseudo-nuclear invaginations were another distinctive feature of tumor cells (H\&E staining, with original magnification $\times 400)$. (F) The sclerotic stroma dispersed tumor cells into isolated small nests (H\&E staining, with original magnification $\times 100$ ). The vessels in between were usually dilated and some of them resembled the changes of papillary endothelial hyperplasia (inserted panel, H\&E staining, with original magnification $\times 400$ ).

The majority of the neoplastic cells were enlarged with marked eosinophilic cytoplasm that sometimes contained sharply delineated lipid vacuoles. A few cells showed highly vacuolated and clear cytoplasm. The nuclei were generally eccentric, mildly to moderately pleomorphic with coarse granular chromatin, resembling the rhabdoid cells (Figure 1C, D). The nucleoli were inconspicuous. However, there were many prominent intranuclear cytoplasmic pseudoinclusions (Figure 1E). Mitotic figures were detectable but were exceedingly rare.

The tumor cells displayed an alternation of cellular and reticular growth patterns. In the former, zellballen- like cellular clusters of neoplastic cells enclosed discrete and sparse vessels. In the latter, trabeculae of neoplastic cells were traversed by abundant slit-like sinusoids. In regions with extensive stromal fibrosis, the tumor cells were dispersed and progressively replaced by hyalinized collagen. The coupled vessels were remained and were frequently dilated (Figure 1F).

Reticular fibers enclosed both tumor cells and vasculature in the areas of reticular growth pattern, but barely surrounded the vessel walls in the regions of cellular growth pattern (Figure 2). PAS staining for glycogen was negative in tumor cells. 


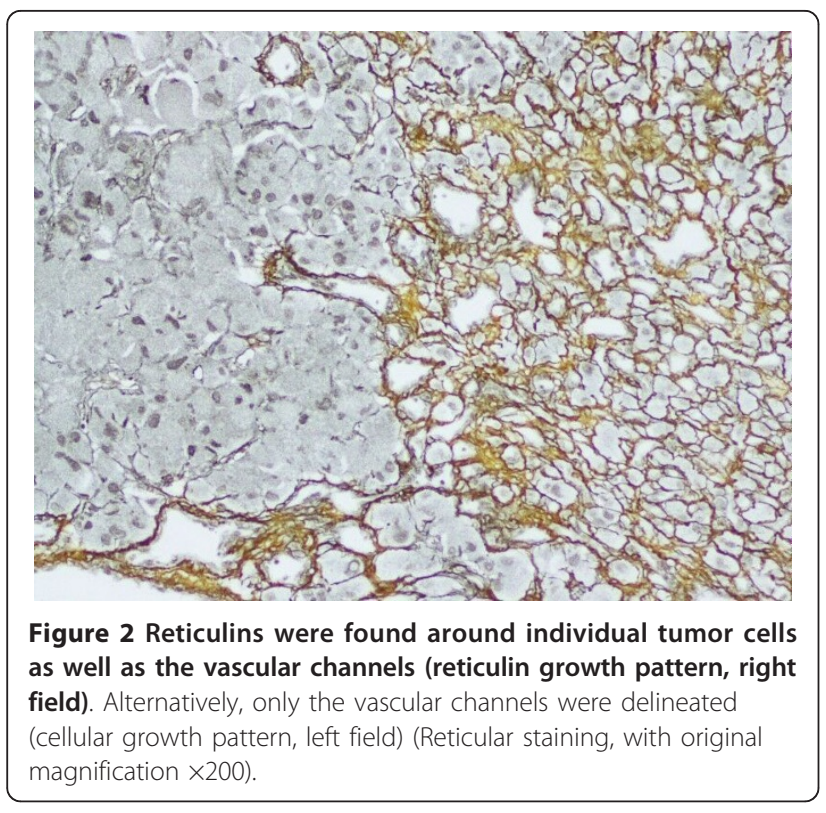

The neoplastic cells displayed diffuse immunoreactivity for a-inhibin, NSE, S100, vimentin and EGFR. Focal membranous staining was noted for CD10 and EMA. The Ki-67 index was approximately 1\%. CD34 outlined the vascular structures (Figure 3). There was no positive staining for AE1/AE3, CK8/18, CK19, gp200, calretinin, HMB-45, Melan-A, chromogranin, Desmin, Actin, Myoglobin and CD68 (Table 1).

\section{Discussion}

Renal haemangioblastoma (RHB) is extremely uncommon since only four cases were definitely reported previously (Table 2). Our case was specifically in line with the diagnostic clues of RHB suggested by Ip et al [5] and Verine et al [6]. Those characteristics included circumscribed borders, paucity of mitotic figures, fine vacuoles in some tumor cells indicating presence of intracytoplasmic lipids, and a rich capillary network. The immunoprofiles (S100 +, NSE+, a-inhibin + and AE1/AE3-) also conformed to those of haemangioblastomas. However, the majority of the tumor cells in our case showed rhabdoid features, which may be easily mistaken for other rhabdoid tumors that are known to occur in the kidney.

In our opinion, the first differential consideration is the malignant rhabdoid tumors (MRTs). Although most of MRTs afflict young children, there still are sporadic cases affecting adults $[7,8]$. Several features seen in our case do not support the diagnosis of MRTs: (i) MRTs generally show vesicular chromatin, prominent nucleoli and hyaline intracytoplasmic inclusion [8]. The neoplastic cells in our case demonstrated dark-stained and coarse granular chromatin, and lack the discernable nucleoli as well as cytoplasmic inclusions. (ii) MRTs are devoid of the cytoplasmic lipid droplets and arborizing stromal vasculature, characterized by haemangioblastomas. (iii) Immunohistochemically, MRTs occasionally are focally positive for S100 and NSE [9], but a-inhibin staining was not shown. The features are different from the extensive expression of S100, NSE and a-inhibin seen in RHB. (IV) MRTs are a highly invasive and lethal neoplasm with a proliferation index of Ki-67 around 95\% [8]. In contrast, the extremely low Ki-67 index and rare mitosis indicate an indolent behavior of our case.

Another necessary differential consideration is renal cell carcinomas with rhabdoid features (RCCR), which have been previously described $[10,11]$. RCCR are predominantly composed of large polygonal cells with eccentric nuclei and eosinophilic cytoplasm. Of the 23 cases analyzed by Gökden et al. [10], RCCR showed a diffuse NSE staining (79\% of cases) and focal positive staining for EMA (47\% of cases) and S-100 (37\% of cases), whereas cytokeratin expression was decreased (56\% of cases). Obviously, there are many morphologic and immunophenotypic features that markedly overlap with our present case. Nevertheless, compared with RCCR, the tumor cells of our case did not display the vesicular nuclei and prominent nucleoli. Furthermore, RHB is characterized by abundant vascular networks, which are strikingly reduced in RCCR [11]. In addition, RHB demonstrates negative PAS staining for glycogen, whereas this staining is positive in RCCR [11]. The low $\mathrm{Ki}-67$ index in our case is also not compatible with the high proliferative index in RCCR [12].

Other neoplasms with rhabdoid features possibly that need to be considered before making the diagnosis of RHB include epithelioid angiomyolipoma ( $\mathrm{HMB}-45^{+}$and Melan- $\mathrm{A}^{+}$), malignant melanoma with rhabdoid features $\left(\right.$ HMB $-45^{+}$and Melan- $\mathrm{A}^{+}$) [13], paraganglioma (synaptophysin $^{+}$, chromogranin ${ }^{+}$and a-inhibin ${ }^{-}$), epithelioid leiomyosarcoma with rhabdoid features $\left(\mathrm{SMA}^{+}\right.$, desmin $^{+}$and $\mathrm{S} \mathrm{O0}^{-}$) [14], and epithelioid malignant peripheral nerve sheath tumor (a-inhibin ${ }^{-}$) [15].

Interestingly, focal CD10 positivity was observed in some tumor cells of our present case. In the normal kidney, CD10 stains glomerular cells and proximal convoluted tubules, and participates in the regulation of water and sodium metabolism [16]. Thus, CD10 expression in RHB seemingly substantiates the earlier hypothesis that haemangioblastomas are derived from pluripotent mesenchymal cells, and partially acquire some site-specific markers of their parental organs during pathogenesis [4]. Many studies have suggested CD10 is a powerful marker in the differentiation between renal cell carcinoma and haemangioblastoma since it usually demonstrates positive staining in renal cell carcinoma while is steadily negative in haemangioblastoma [17]. Our result indicates that caution should be taken on evaluating the differential efficacy 


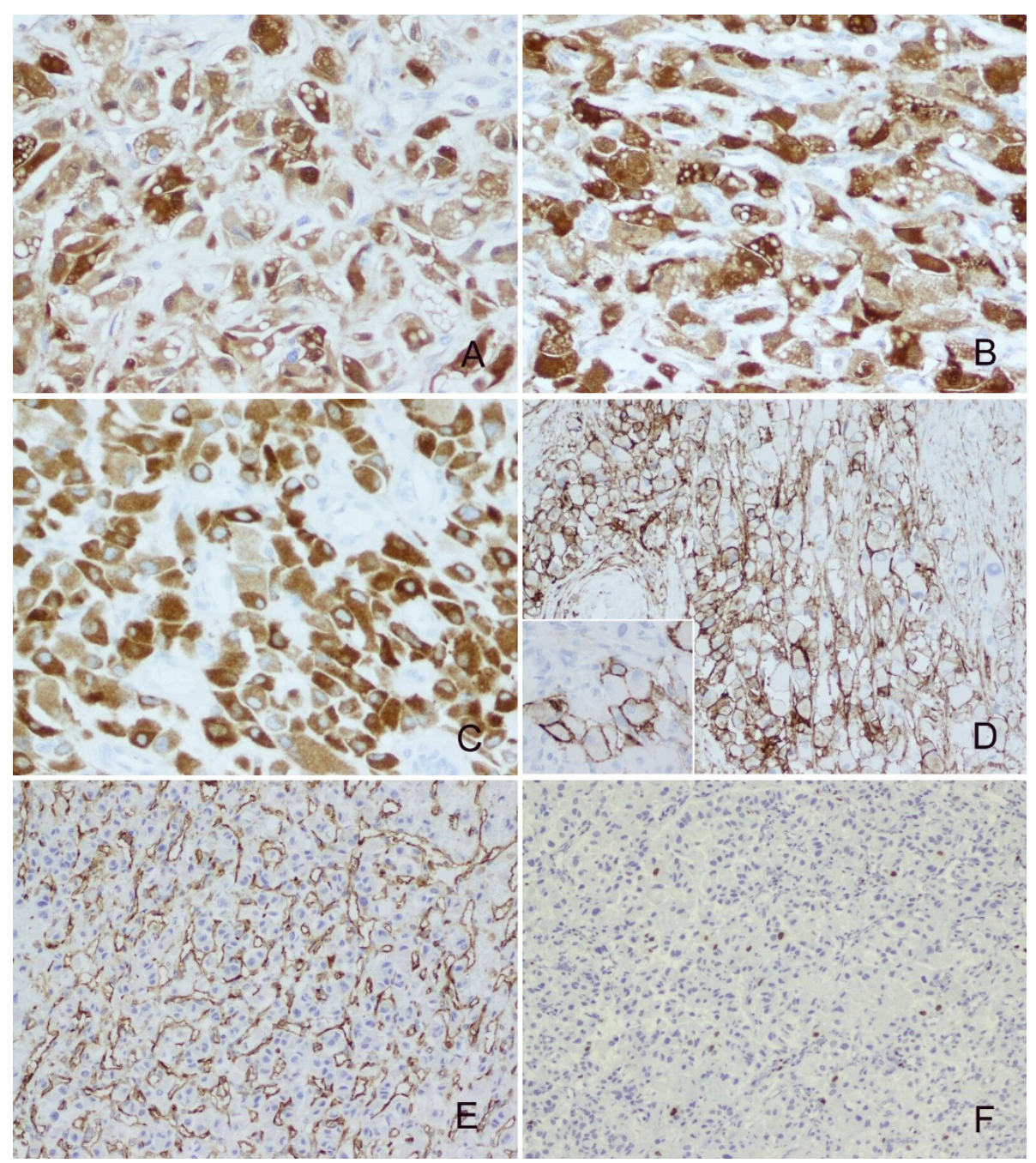

Figure 3 Immunoprofiles of the renal hemangioblastoma. The neoplastic cells showed diffuse positive staining for S100 (A), NSE (B) and ainhibin $(\mathbf{C})$ (with original magnification $\times 400$ ). Some tumor cells were immunoreactive with CD10 (with original magnification $\times 200)$ and bright membrance staining were observed (inserted panel, with original magnification $\times 400)(\mathbf{D})$. CD34 underlined the rich vascular channels $(\mathbf{E})($ with original magnification $\times 200$ ). The Ki-67 index was around $1 \%(\mathbf{F})$ (with original magnification $\times 100$ ).

of this reagent. Noticeably, Verine et al. [6] reported a negative result of CD10 staining in their case of RHB. The reasons for the discrepancy remain unknown, and probably either reflect the intrinsic disparities of expressional profiles between the two specimens, or may be just caused by different antibodies used.

Some investigators have suggested that RHB would not be as rare if it had got wider recognition as a primary renal tumor $[5,6]$. So it is undoubtedly necessary to be aware of the clinicopathologic characteristics of RHB. From the available data, RHB commonly occurs in the elderly people (range 55 to 71 years) and there is no sex predilection. The right kidney seems more prone to be affected and the superior pole is likely the preferential site of mass development. Grossly, these tumors displayed a solid cut surface, though cystic changes were occasionally observed. Architecturally, the lesions were consistently composed of cellular and paucicellular regions. In the cellular areas, the tumor could be subclassified as reticular and cellular variants analogous to cerebellar haemangioblastoma [18]. In the paucicellular zones, stromal fibrosis was prominent. Cytologically, the neoplastic cells in RHB generally contained mild to remarkably eosinophilic cytoplasm and frequently outnumbered the clear cells with rich lipid droplets. The nuclei were often enlarged and hyperchromatic, and frequently displayed some pleomorphism. In addition to the positivity for S100, a-inhibin and NSE, focal expression of EMA, SMA, MSA and calponin were also noted [5]. Nevertheless, Cytokeratins, HMB-45, Melan-A, 
Table 1 Panel of immunohistochemical stains

\begin{tabular}{|c|c|c|c|c|}
\hline Immunohistochemical stains & Clone & Sources & Dilution & Results \\
\hline Pan cytokeratin & AE1/AE3 & Neomarkers & $1: 100$ & Neg. \\
\hline Keratin $8 / 18$ & $5 \mathrm{D} 3$ & Neomarkers & $1: 200$ & Neg. \\
\hline Keratin 19 & RCK108 & Neomarkers & $1: 200$ & Neg. \\
\hline Renal Cell Carcinoma Marker(gp200) & $\mathrm{PN}-15$ & Neomarkers & 1:100 & Neg. \\
\hline Neuron-specific enolase (NSE) & NSE-P1 & Neomarkers & $1: 1500$ & Pos. \\
\hline Epithelial membrane antigen (EMA) & E29 & Neomarkers & $1: 500$ & Pos. (focal) \\
\hline CD10 & $56 C 6$ & Neomarkers & $1: 50$ & Pos. (focal) \\
\hline $\mathrm{Ki}-67$ & SP6 & Neomarkers & 1:500 & Pos. (1\%) \\
\hline Vimentin & SP20 & Neomarkers & $1: 300$ & Pos. \\
\hline S100 protein & Polyclonal antiserum & Dako & $1: 6000$ & Pos. \\
\hline a-inhibin & R1 & Dako & $1: 1250$ & Pos. \\
\hline Epidermal growth factor receptor (EGFR) & EP38Y & Neomarkers & $1: 100$ & Pos. \\
\hline calretinin & SP13 & Neomarkers & 1:100 & Neg. \\
\hline Melanoma Marker & HMB45 & Neomarkers & $1: 50$ & Neg. \\
\hline Melan-A & A103 & Neomarkers & 1:100 & Neg. \\
\hline Chromogranin A & SP12 & Neomarkers & $1: 200$ & Neg. \\
\hline Desmin & Rabbit Polyclonal Antibody & Neomarkers & $1: 200$ & Neg. \\
\hline Actin & HHF35 & Neomarkers & 1:100 & Neg. \\
\hline Myoglobin & Rabbit Polyclonal Antibody & Neomarkers & 1:800 & Neg. \\
\hline CD68 & PG-M1 & Neomarkers & $1: 100$ & Neg. \\
\hline CD34 & QBEnd/10 & Neomarkers & $1: 80$ & Neg. \\
\hline
\end{tabular}

chromogranin, calretinin, and Myoglobin were characteristically negative.

Compared with cerebellar haemangioblastoma (CHB), RHB manifest with some different features. For instance, RHB incidence peaks in the sixth decade compared to the fourth decade of CHB [19]. RHB usually presents as a solid mass, whereas 65 percent of CHB manifest as a cystic mass [20]. The acidophilic cytoplasm and pleomorphic nuclei that are frequently present in renal tumors are usually not seen in CHB. Stromal hyalinization in RHB is

Table 2 Clinicopathological characteristics of the reported sporadic hemangioblastomas in the kidney

\begin{tabular}{|c|c|c|c|c|c|c|c|c|c|}
\hline \multirow[t]{2}{*}{ Case } & \multirow{2}{*}{$\begin{array}{l}\text { Age } \\
(y) / \\
\text { Sex }\end{array}$} & \multirow[t]{2}{*}{ Gross features } & \multicolumn{4}{|c|}{ Histological features } & \multicolumn{2}{|c|}{$\begin{array}{l}\text { Immunohistochemical } \\
\text { staining }\end{array}$} & \multirow{2}{*}{$\begin{array}{c}\text { Treatment/ } \\
\text { Follow-up } \\
\text { (y) }\end{array}$} \\
\hline & & & Cytoplasm & Nuclear & Necrosis & $\begin{array}{l}\text { Stromal } \\
\text { fibrosis }\end{array}$ & Diffuse & Focal & \\
\hline 1 (ref.4) & $\begin{array}{c}71 / \\
\text { female }\end{array}$ & $\begin{array}{l}\text { Solid with } \\
\text { scattered cystic } \\
\text { spaces; located } \\
\text { in right kidney }\end{array}$ & $\begin{array}{l}\text { Amphophilic to } \\
\text { clear }\end{array}$ & $\begin{array}{c}\text { Round with delicate } \\
\text { chromatin; lack of mitoses }\end{array}$ & Absent & Present & a-inhibin & $\begin{array}{l}\text { Vimentin, } \\
\text { S100, SMA, } \\
\text { MSA, } \\
\text { calponin }\end{array}$ & NP/AW/9 \\
\hline $2($ ref.5) & $\begin{array}{l}58 / \\
\text { male }\end{array}$ & $\begin{array}{l}\text { Solid with a } \\
\text { cystic cavity; } \\
\text { located in right } \\
\text { kidney }\end{array}$ & Eosinophilic & $\begin{array}{l}\text { Mildly to highly pleomorphic; } \\
\text { lack of mitoses }\end{array}$ & Absent & Present & $\begin{array}{l}\text { a-inhibin, } \\
\text { S100, } \\
\text { NSE, } \\
\text { GLUT1 }\end{array}$ & & $\mathrm{NP} / \mathrm{AW} / 2$ \\
\hline 3(ref.5) & $\begin{array}{c}55 / \\
\text { female }\end{array}$ & $\begin{array}{l}\text { Solid; located in } \\
\text { right kidney }\end{array}$ & $\begin{array}{l}\text { Eosinophilic; } \\
\text { variable-sized } \\
\text { hyaline globules } \\
\text { were found }\end{array}$ & $\begin{array}{l}\text { Mildly to highly pleomorphic; } \\
\text { very sparse mitoses }\end{array}$ & Present & Present & $\begin{array}{l}\text { a-inhibin, } \\
\text { S100, } \\
\text { NSE, } \\
\text { GLUT1 }\end{array}$ & & NP/AW/4 \\
\hline 4(ref.6) & $\begin{array}{l}\text { 64/ } \\
\text { male }\end{array}$ & $\begin{array}{l}\text { Solid; located in } \\
\text { left kidney }\end{array}$ & $\begin{array}{c}\text { Weakly } \\
\text { eosinophilic }\end{array}$ & $\begin{array}{l}\text { Enlarged and slightly atypical; } \\
\text { lack of mitoses }\end{array}$ & Absent & Present & $\begin{array}{c}\text { S100, } \\
\text { NSE, } \\
\text { Vimentin }\end{array}$ & $\begin{array}{l}\text { EMA, a- } \\
\text { inhibin }\end{array}$ & pNP/AW/4 \\
\hline $\begin{array}{c}5 \\
\text { (present } \\
\text { case) }\end{array}$ & $\begin{array}{l}61 / \\
\text { male }\end{array}$ & $\begin{array}{l}\text { Solid; located in } \\
\text { right kidney }\end{array}$ & $\begin{array}{l}\text { Eosinophilic; } \\
\text { exhibiting a } \\
\text { rhabdoid } \\
\text { phenotype }\end{array}$ & $\begin{array}{l}\text { Mildly to highly pleomorphic; } \\
\text { intranuclear cytoplasmic } \\
\text { pseudoinclusions were } \\
\text { present; sparse mitoses }\end{array}$ & Present & Present & $\begin{array}{l}\text { a-inhibin, } \\
\text { S100, } \\
\text { NSE, } \\
\text { EGFR }\end{array}$ & CD10, EMA & NP/AW/1 \\
\hline
\end{tabular}

$\mathrm{NP}$, nephrectomy; pNP, partial nephrectomy; AW, alive and well 
also more prominent than that in CHB. However, the immunophenotype and benign behaviors of RHB reflect the essential consistency with $\mathrm{CHB}$.

\section{Conclusions}

We have presented another case of RHB, which demonstrates distinctive rhabdoid features and focal CD10 expression. The tumor cells of RHB generally show abundant acidophilic cytoplasm and pleomorphic nuclei, whereas the characteristic stromal cells with finelyvacuolated lipid droplets are not usually prominent. Diffuse expression of S100, a-inhibin and NSE are very helpful to narrow down the differential diagnoses. The unexpected positive staining of CD10 in RHB should be particularly concerned. RHB have excellent prognosis, and tumor necrosis and nuclear pleomorphism do not seem to affect the prognosis. Most importantly, RHB should be included in the differential diagnosis of primary renal tumors.

\section{Consent}

Written informed consent was obtained from the patient for publication of this case report and accompanying images. A copy of the written consent is available for review by the Editor-in Chief of this Journal.

\section{Acknowledgements}

The authors express their sincere appreciation of the language editing assistance given by Keiyan Sy, MD, Department of Laboratory Medicine and Pathobiology, University of Toronto, Canada and Laibao Sun, MD Department of Anatomic Pathology, Sunnybrook Health Sciences Centre, Toronto, Canada.

\section{Author details}

${ }^{1}$ Department of Pathology, Peking University Shenzhen Hospital, No.1120 Lianhua North Road, Shenzhen 518000, China. ${ }^{2}$ Department of Pathology, Queen Elizabeth Hospital, Hong Kong, SAR, China.

\section{Authors' contributions}

W-HY designed the study, performed the histological and immunohistochemical evaluation, literature review and drafted the manuscript. $J$ participated in histological diagnosis and immunohistochemical evaluation, literature review and revised the manuscript. JKCC participated in histological diagnosis. All authors read and approved the final manuscript.

\section{Competing interests}

The authors declare that they have no competing interests.

Received: 2 January 2012 Accepted: 12 April 2012

Published: 12 April 2012

\section{References}

1. Panelos J, Beltrami G, Capanna R, Franchi A: Primary capillary hemangioblastoma of bone: report of a case arising in the sacrum. Int J Surg Pathol 2008, 18:580-583.

2. MCGrath FP, Gibney RG, Morris DC, Owen DA, Erb SR: Case report: multiple hepatic and pulmonary haemangioblastomas-a new manifestation of von Hippel-Lindau disease. Clin Radiol 1992, 45:37-39.

3. Boyd AS, Zhang J: Hemangioblastoma arising in the skin. Am J Dermatopathol 2001, 23:482-484.
4. Nonaka D, Rodriguez J, Rosai J: Extraneural hemangioblastoma: a report of 5 cases. Am J Surg Pathol 2007, 31:1545-1551.

5. Ip YT, Yuan JQ, Cheung H, Chan JK: Sporadic hemangioblastoma of the kidney: an underrecognized pseudomalignant tumor? Am J Surg Pathol 2010, 34:1695-1700.

6. Verine J, Sandid W, Miquel C, Vignaud JM, Mongiat-Artus P: Sporadic hemangioblastoma of the kidney: an underrecognized pseudomalignant tumor? Am J Surg Pathol 2011, 35:623-624.

7. Ebbinghaus SW, Herrera G, Marshall ME: Rhabdoid tumor of the kidney in an adult: review of the literature and report of a case responding to interleukin-2. Cancer Biother 1995, 10:237-241.

8. Peng HQ, Stanek AE, Teichberg S, Shepard B, Kahn E: Malignant rhabdoid tumor of the kidney in an adult: a case report and review of the literature. Arch Pathol Lab Med 2003, 127:e371-373.

9. Wick MR, Ritter JH, Dehner LP: Malignant rhabdoid tumor: a clinicopathologic review and conceptual discussion. Semin Diagn Pathol 1995, 12:233-248.

10. Gökden N, Nappi O, Swanson PE, Pfeifer JD, Vollmer RT, Wick MR, Humphrey PA: Renal cell carcinoma with rhabdoid features. Am J Surg Pathol 2000, 24:1329-1338.

11. Shannon B, Stan Wisniewski Z, Bentel J, Cohen RJ: Adult rhabdoid renal cell carcinoma. Arch Pathol Lab Med 2002, 126:1506-1510.

12. Ma J, Zhou XJ, Huang WB, Zhou HB, Jiang SJ, Rao Q, Lu ZF, Shi QL: Clinicopathologic study of renal cell carcinoma with rhabdoid features. Zhonghua Bing Li Xue Za Zhi 2007, 36:166-170.

13. Abbott JJ, Amirkhan RH, Hoang MP: Malignant melanoma with a rhabdoid phenotype: histologic, immunohistochemical, and ultrastructural study of a case and review of the literature. Arch Pathol Lab Med 2004, 128:686-688.

14. Yorulmaz G, Erdogan G, Pestereli HE, Savas B, Karaveli FS: Epithelioid leiomyosarcoma with rhabdoid features. Wien Klin Wochenschr 2007, 119:557-560.

15. Gulati N, Rekhi B, Suryavanshi P, Jambhekar NA: Epithelioid malignant peripheral nerve sheath tumor of the uterine corpus. Ann Diagn Pathol 2011, 15:441-445.

16. Chu P, Arber DA: Paraffin-section detection of CD10 in 505 nonhematopoietic neoplasms. Frequent expression in renal cell carcinoma and endometrial stromal sarcoma. Am J Clin Pathol 2000, 113:374-382.

17. Jung SM, Kuo TT: Immunoreactivity of CD10 and inhibin alpha in differentiating hemangioblastoma of central nervous system from metastatic clear cell renal cell carcinoma. Mod Pathol 2005, 18:788-794

18. Rickert $\mathrm{CH}$, Hasselblatt $\mathrm{M}$, Jeibmann A, Paulus W: Cellular and reticular variants of hemangioblastoma differ in their cytogenetic profiles. Hum Pathol 2006, 37:1452-1457.

19. Aldape KD, Plate KH, Vortmeyer AO: Hemangioblastoma. In WHO Classification of Tumours of the Central Nervous System.. 4 edition. Edited by: Louis DN, Ohgaki H, Wiestler OD. IARC: Lyon; 2007:184-186.

20. Slater A, Moore NR, Huson SM: The natural history of cerebellar hemangioblastomas in von Hippel-Lindau disease. AJNR Am J Neuroradiol 2003, 24:1570-1574.

doi:10.1186/1746-1596-7-39

Cite this article as: Yin et al:: Sporadic haemangioblastoma of the kidney with rhabdoid features and focal CD10 expression: report of a case and literature review. Diagnostic Pathology 2012 7:39. 